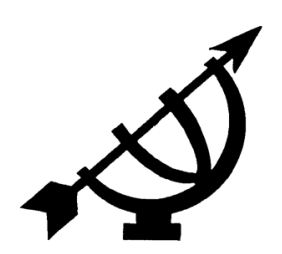

\title{
Die informatisering van ons mensbeeld
}

\author{
C.S. de Beer \\ Departement Inligtingkunde \\ Universiteit van Pretoria \\ PRETORIA \\ E-pos: fanie.debeer@up.ac.za
}

Abstract

\section{The informatisation of our image of the human being}

Serious reflection is required to determine our position regarding our image of the human being. The image we maintain is of critical importance. It determines interhuman relations and human action. The traditional notion of the human subject as absolute, self-certain and autonomous has been comprehensively questioned for some decades and can be considered outdated. This rethinking has a long history and a diversity of insights has been developed by many influential thinkers. Processes of informatisation play a significant role in the development of these different perspectives.

Three developments seem prominent. The first is the development of the notion of the so-called "decentred subject". The second development puts more emphasis on the mechanical more specifically the mechanisation of the mind, with the consequent renunciation of human spirituality. This perspective is a predecessor of the third development which entails a further degeneration of human subjectivity. Non-corporeal consciousness can now be downloaded onto computers. The figure of the posthuman emerges. Problems of fallibility, mortality and ageing will disappear. Although such an apocalyptic viewpoint may indeed sound tempting, it leaves many crucial questions unanswered.

On the other hand, when dealt with differently, this process of rethinking brings forward some rich and new articulations of what it means to be human, which can be of great significance for individuality and sociality in the light of the crises that threaten to fatally derail contemporary societies worldwide. It is, 
moreover, not totally unrelated to the other three ways and receives its inspiration from them.

\section{Opsomming}

\section{Die informatisering van ons mensbeeld}

Diepgaande refleksie is nodig om te bepaal waar ons vandag met ons voorgestelde beeld van die mens staan. Die beeld wat ons handhaaf, is van die uiterste belang. Dit bepaal tussenmenslike verhoudings en ook menslike handeling. Die tradisionele opvatting van die menslike subjek as absoluut, selfversekerd en outonoom is gedurende die afgelope dekades deeglik bevraagteken en kan as uitgedien beskou word. Hierdie herdinkproses het 'n lang geskiedenis en 'n verskeidenheid insigte is deur baie invloedryke denkers ontwikkel. Informatiseringsprosesse speel 'n betekenisvolle rol in die ontwikkeling van hierdie verskillende perspektiewe.

Drie ontwikkelings blyk voorrang te geniet. Die eerste is die ontwikkeling van die nosie van die sogenaamde "gedesentreerde subjek". Die tweede ontwikkeling plaas meer klem op die meganiese - die meganisering van die gees, waarin afstand gedoen word van die menslike gees. Hierdie perspektief is die voorloper van die derde ontwikkeling wat 'n verdere degenerasie van die menslike subjektiwiteit behels. Die liggaamlose bewussyn kan nou op rekenaars afgelaai word. Die posthumane figuur verskyn. Probleme van feilbaarheid, sterflikheid en veroudering gaan verdwyn. Hoewel so 'n apokaliptiese uitgangspunt besonder belowend klink, laat dit heelwat belangrike vrae onbeantwoord.

Aan die ander kant kan hierdie herdinkproses sekere ryk en nuwe artikulasies na vore bring oor wat dit beteken om mens te wees. Dit kan ook van groot betekenis wees vir individualiteit en sosialiteit in die lig van die krisisse wat wêreldwyd dreig om hedendaagse samelewings op 'n fatale wyse te laat ontspoor. Dit is egter ook nie heeltemal onverwant aan die ander drie ontwikkelings nie en kry selfs inspirasie daaruit.

\section{Inleiding}

Diepgaande refleksie is nodig om te bepaal waar ons vandag staan ten opsigte van die idee van die mens (Janicaud, 2005) - met ons voorgestelde beeld van die mens, met ons begrip van wat dit beteken om mens te wees. Wie presies is die mens? Hoe dink ons oor die mens? Wat kan van die mens verwag word? Guattari $(1995: 135)$ skryf: 
Among the fogs and miasmas which obscure our fin de millenaire the question of subjectivity is now returning as a leitmotif. ... How do we produce it, capture it, enrich it, and permanently reinvent it in a way that renders it compatible with Universes of mutant value? How do we work for its liberation, that is, for its resingularisation? ... All disciplines will have to combine their creativity to ward off the ordeals of barbarism, the mental implosion and chaosmic spasms looming on the horizon, and transform them into riches and unforeseen pleasures ...

Wanneer 'n mens kyk na die geweldige hoeveelheid werk wat tans gedoen word oor die vraag na die betekenis van menswees en oor die mens as subjek, kan ons nie anders nie as om hierdie omvattende onderneming te sien as 'n reeks nuwe maniere om na die mens te kyk, om te antwoord op die soort oproepe van Janicaud en Guattari. Die menslike wese, subjek, ego, ek, bewussyn, individu, humanisme, posthumane, transhumanisme, inhumane, selfs kuborg is almal terme wat ten opsigte van hulle inhoud verbind moet word met hierdie hoeveelheid werk en met pogings om menslike subjektiwiteit te herdefinieer en te herinventeer. Almal verteenwoordig pogings om op die stelling in die inleidende sin en die vrae van Guattari te antwoord. Die betekenisse wat gegee word, is egter wyd uiteenlopend. Die vraag kan ook gestel word of dit hoegenaamd nodig is om ' $n$ antwoord te gee. ' $n$ Antwoord is egter onvermydelik. Hoe daar gekyk word na die mens en hoe daar verstaan word wie die mens is, bepaal hoe daar gehandel word.

Baie mense is opgevoed met 'n klassieke mensopvatting wat 'n geruime tyd al ernstig van verskillende kante bevraagteken word. Die Cartesiaanse, Kantiaanse en Hegeliaanse mensopvattings waarin die mens gesien word as 'n absolute, selfversekerde, verenigde wese, die ek of die self, toegerus met 'n positiewe selfbeeld (altans, so behoort dit te wees), is die beeld wat gehandhaaf word en waarna gestrewe word. Hierdie grootword- en opvoedingsproses is prosesse waardeur ons ingelig is oor hoe daar oor ons menswees gedink behoort te word. Die beeld wat ons oor die mens huldig, is 'n ingeligte, geïnformatiseerde beeld. Ons is oor ons mensbeeld vertel, moes en kon daaroor lees, het daaroor gepraat, het dit oorvertel ander is deur ons daaroor ingelig. Nuwe terme het na vore gekom wat feitlik dieselfde inligting oorgedra het en steeds vertel. Die "liberale subjek" is sedert die Verligting gesien as die ideale beeld van die subjek (Baker, 1961). Alles is nog deel van verskuiwings in die aksente van die informatiseringsproses. Hierdie proses dwing 
ons om deeglik daaroor te besin waar ons tans met ons mensbeeld staan.

\section{Die herdink van die menslike subjek, fase 1: radikale hersiening}

Gaandeweg het modelle van subjektiwiteit na vore gekom wat aansienlik van die humanisme van die genoemde liberale subjek verskil. Soper (1986) het die verbandhoudende debat oor humanisme en anti-humanisme indringend bespreek. Daar is ook al hoe meer mense wat hulle assosieer met een of ander van hierdie nuwe subjektiwiteitsmodelle. Die ek, of die self, word nie meer as 'n individu of as selfstandig en outonoom gesien nie, maar as meervoudig, kollektief of selfs fraktaal. (Vgl. Baudrillard, 1989; Wersig, 1995; Nancy, 1996; Serres, 2001). Die ek is versnipper, verdeel en afhanklik. Miskien was daar nooit volledige eenstemmigheid daaroor om aan die sogenaamde self-made man 'n ereplek te verskaf nie en tog het dit gebeur. Bakker (1981:15) stel dit soos volg:

De mens is, aldus Scheler, een 'so breites, buntes, mannigfaltiges Ding, dass die Definitionen all ein wenig zu kurz geraten. Er hat zu viele Enden'.

Dit herinner ' $n$ mens baie aan van die meer onlangse beskrywings van die mens. Op 'n insiggewende wyse vra Habermas (2002) na die toekoms van die menslike natuur en betoog Singer (2003) vanuit die neuro-wetenskappe ten gunste van 'n nuwe mensbeeld.

Die soeke na die nuwe, na iets beters, is natuurlik geen vreemde verskynsel nie. Die Ou en Nuwe Testamente, die Renaissance, die Verligting, die Postmodernisme (nou die posthumane), verteenwoordig almal sodanige soektogte na die nuwe. Ons eie tyd is ook vol daarvan. Serres se Hominescence (2001) en sy bespreking van die humanisme (2006) artikuleer presies hierdie drif wanneer hy dit stel dat ons aan die begin staan van 'n nuwe mensheid of 'n nuwe mensopvatting. Terselfdertyd word die nuutheid deur onsekerheid omring. Hy skryf:

Ons lewe in 'n beslissende tydstip van die proses wat vorm gee aan ons lewe. Hierdie geboorte [van 'n nuwe soort humaniteit] stem baie mense tot groot onrus, maar wek tog entoesiasme by ander. Ons ontlok dit sonder om te weet watter soort mens dit skep, tot niet maak of verheerlik. (Serres, 2001:294; vertaling CSdeB.) 
Informatiseringsprosesse speel 'n al hoe groter rol in hierdie vernuwing van die mensbeeld. Filosofiese perspektiewe het die weg voorberei. Miskien was Heidegger een van die eerstes om so 'n aksentverskuiwing aan te dui deur ons terug te neem na die Grieke. Sy gretigheid om die mens as subjek in 'n synsverhouding te beskryf, het die klassieke humanisme probeer troef in Die tyd van die wêreldbeeld (Heidegger, 1983) asook sy brief oor die Humanisme (Heidegger, 1973), waarin hy die humane en die inhumane ter sprake bring. In laasgenoemde wys hy daarop dat die subjekbegrip ' $n$ vertaling is van die Griekse term hupokeimenon. Hierdie woord behels "het voor-liggende, dat als grond alles op zich verzamelt" (Heidegger, 1983:45). Hy verwys na Parmenides en stel dit soos volg:

Het zijnde is het opkomende en het zich openende, datgene wat als het aanwezige over de mens als de aanwezige komt, d.w.s. over degene die zichzelf voor het aanwezige opent, doordat hij het verneemt. Het zijnde wordt niet 'zijnd' doordat de mens het eerst aanschouwt, in de zin nog wel van een voorstelling volgens de aard van een subjectieve perceptie. Veeleer is het de mens die door het zijnde aanschouwt wordt, door datgene wat zich opent naar het aanwezen toe, dat bij hem verzamelt is. Door het zijnde aanschouwt, in zijn openheid opgenomen en bijgehouden en aldus erdoor gedragen, in zijn tegenstellingen heen en weer geslingerd en door tweespalt getekend zijn: ziedaar het wezen van de mens op het hoogtepunt van het griekse tijdperk. Daarom moet deze mens om zijn wezen te vervullen het zijnde dat zich opent in zijn openheid verzamelen en redden, opvangen en bewaren, terwijl hij aan heel de openbrekende verwarring blootgesteld blijft. De griekse mens is degene die het zijnde verneemt. (Heidegger, 1983:48.)

Die volgende aantekening kan by die "verneem van die synde" van pas wees: miskien kan gesê word dat die mens wat verneem, die een is wat luister na dit wat aan hom meegedeel word en dit in ag neem. Die mens, die subjek, die ek word onder andere dus onderrig deur die synde, vorm gegee deur die synde, en heen en weer geslinger deur die synde. Dit klop ook met die "pragmatogonie" van Serres (1987) wanneer hy skryf oor die impak en die vormgewende krag wat objekte en dinge op mense en menslike subjekte het. (Vgl. ook De Beer, 2010b.) Dit is nie net mense wat objekte en dinge bemeester en beheer nie, maar veral ook dinge en objekte wat 'n vormende impak op mense uitoefen.

Ter aansluiting by die gedagtes van Heidegger, word die vraag gestel: What comes after the subject? (Cadava et al., 1991). In die 
inleiding tot hierdie teks wys Nancy daarop dat die herdink of dekonstruksie van die subjek veel meer is as 'n blote modeverskynsel. Hy skryf:

I asked the question: Who comes after the subject? To settle one of the principle rupture lines. The critique or deconstruction of subjectivity is to be considered one of the great motifs of contemporary philosophical work in France, taking off from, here again and perhaps especially, the teachings of Marx, Nietzsche, Freud, Husserl, Heidegger, Bataille, Wittgenstein, from the teachings of linguistics, the social sciences, and so forth. (But one should not forget the practical, ethical, and political experience of Europe since the 1930s: the fascisms, Stalinism, the war, the camps, decolonization, and the birth of new nations, the difficulty in orienting oneself between a 'spiritual' identity that has been devasted and an 'American' economism, between a loss of meaning and an accumulation of signs: so many instances for the investigation of the diverse figures of the 'subject'.) The question therefore bears on the critique or deconstruction of interiority, of self-presence, of consciousness, of mastery, of the individual or collective property of an essence. Critique or deconstruction of the firmness of a seat (hypokeimenon, substantia, subjectum) and the certitude of an authority and a value (the individual, a people, the state, history, work). My question aimed in the first place to treat this motif as an event that had indeed emerged from our history - hence the 'after' - and not as some capricious variation of fashionable thinking. (Cadava et al., 1991:4.)

Die versameling opstelle wat deur Faubion (1995) geredigeer is en van 'n besonder insiggewende inleiding voorsien is, bevestig hierdie gedagtes.

Hierdie reekse opstelle is, soos almal sekerlik weet, voorafgegaan deur heelwat filosofiese werk en ook deeglike werk daarna. Foucault se "einde van die mens" is hiervan 'n voorbeeld wanneer hy skryf: "As the archaeology of our thought easily shows, man is an invention of recent date. And one perhaps nearing its end." (Foucault, 1970:387.) Bakker (1973:30) vat Foucault se beskouing op die volgende manier saam:

Het subject is niet langer meer centrum van betrekkingen. Centrum is de structuur waarbinnen het subject als element van het geheel funktioneert. Het subject is gedecentreerd: het heeft zijn substantie, zijn autarkie verloren aan totaliteit. Het is een funktioneel element in een system. De doorleefde ervaring 
speelt geen enkele rol, want zij is niet funksionalistisch onder te brengen in een logisch-konsekwent systeem van betrekkinge. Dit bedoelt Foucault als hij zegt, dat de mens bestemd is om te verdwijnen, zoals het in het zand getekende gelaat in een vloedgolf verdwijnt.

Derrida (1982) se dekonstruksie van die subjek kom eweneens neer op 'n desentrering van die subjek. Volgens Derrida is daar reeds spore van hierdie bevraagtekening aanwesig in Kant, Hegel en Husserl alhoewel slegs 'n baie deurdagte lesing van hulle tekste dit sal openbaar. In 'n omvattende versamelbundel wat oor hierdie werk van Derrida saamgestel is, skryf die redakteurs, Lacoue-Labarthe en Nancy (1981:13), dat die vraag na die mens nie langer die blinde vraag na "die wese van die mens" kan wees waarin identiteit of eiendomlikheid vasgelê is nie, maar dat daar eerder gevra moet word wie die mens Is. Dit sal tot 'n deïdentifisering en 'n defigurering en 'n onteiening lei. "Hoe kragtiger die veronderstelling van die wesenlike en die eiendomlike is, hoe meer onvermydelik, omvangryk en enkelvoudig word die ont-eiening." (Vertaling - CSdeB.) Nog 'n voorbeeld wat reeds genoem is, is Baudrillard (1989) se veelseggende artikel oor fraktaliteit. Die Nederlandse en Vlaamse tale bied bruikbare hulp en inleiding in hierdie herbesinning. Vergelyk Het anonieme denken van Bakker (1973), die ewe betekenisvolle Denken in Parijs van Berns et al. (1979) en die insiggewende Mensbeelden van Kwant (1973) om slegs drie te noem.

Van die insiggewendste opmerkings oor subjektiwiteit is moontlik Deleuze en Guattari (1988:3) se standpunt in die inleiding tot Duisend plateaus waarin die volgende veelseggende kernpunte na vore gebring word:

The two of us wrote Anti-Oedipus together. Since each of us was several, there was already quite a crowd. Here we have made use of everything that came within range, what was closest as well as farthest away. We have assigned clever pseudonyms to prevent recognition. Why have we kept our own names? Out of habit, purely out of habit. To make ourselves unrecognizable in turn. To render imperceptible, not ourselves, but what makes us act, feel and think. Also because it is nice to talk like everybody else, to say the sun rises, when everybody knows it is only a matter of speaking. To reach not the point where one no longer says I, but the point where it is no longer of importance whether one says I. We are no longer ourselves. Each will know his own. We have been aided, inspired, multiplied. 
'n Verwysing na die psigoanalise en spesifiek ook na Lacan (1977: 292-325) se "ondergrawing van die subjek" is insiggewend. Die subjek as eenheid verval. Sodra daar met die onbewuste van die psigoanalise rekening gehou moet word, verander die beeld van die subjek radikaal. In sy verhouding tot kennis, word die dubbelsinnigheid van die verhouding beklemtoon. Die subjek wat moet weet wat hy doen, weet nie regtig wat die effek van kennis in almal se belang werklik is nie. Onsekerheid eerder as sekerheid moet beklemtoon word. 'n Mens het hier te doen met 'n "verdeelde subjek".

Hierdie desentrering van die subjek bly steeds 'n intrahumane aktiwiteit. Dit bly ' $n$ worsteling van die mens met homself, wie hy is, wil, of moet wees. Daarom bly etiek en moraliteit inherent deel van hierdie diskoers. Dit mag wel 'n postmoderne diskoers wees, maar nog geen posthumane diskoers nie. Het Foucault $(2008 ; 2009)$ nie self ook later bedenkings uitgespreek en uitgedink oor die mens wat bestem is om te verdwyn nie? Sy laaste twee seminaarreekse, wat die outeur (DFMS) bevoorreg was om by te woon en wat albei gepubliseer is, het op ' $n$ besonder betekenisvolle wyse weer die mens, die subjek, nadergetrek en "mooi" gemaak in die vraag na die "mooi" lewe wat hy probeer beantwoord het. Guattari (1995) se soeke na 'n nuwe etiko-estetiese paradigma pas perfek hierby in. Sy vroeëre aanhaling be,vestig dat sy denke swanger is aan 'n ware moraliteitsgevoel. Badiou (2001) se etiek is 'n verdere bevestiging hiervan en bevat 'n sinvolle besinning oor die subjek. Lacan (1986) se etiek van die psigoanalise, wat 'n studie in eie reg regverdig, sluit goed hierby aan. Vergelyk veral ook Zupančič (2000) se deeglike studie van Kant en Lacan in 'n etiese verband.

\section{Die meganisering van die gees en die tegnifisering van die subjek}

Daar is egter ook 'n ander beweging met 'n teenoorgestelde effek. Wetenskaplike en tegniese ontwikkelings het 'n groot aandeel in die wyse waarop ons geïnformatiseer word om oor die mens te dink. Dupuy (2000) wys daarop hoe "die meganisering van die gees" die wegbereider en selfs informeerder is tot 'n nuwe mensbeeld in die kognitivistiese wetenskappe. Stiegler (2001) spel dit duidelik uit dat tegniese wetenskappe en ontwikkelings, tesame met die ekonomiese wetenskappe, bydra tot die industrialisering van die gees. Fukuyama (2003:148) verwys ook na die instrumentalisering van die mens na aanleiding van sy bespreking van die konsekwensies van die biotegnologiese revolusie vir die mens se posthumane toekoms. Hiervolgens word menslike geestelike instrumente, meganiese ge- 
bruiksvoorwerpe vir die tegniek en die wetenskap en menslike liggaamlikheid 'n totale oorbodigheid. Geen beter voorloper vir 'n posthumane skepping en invensie is moontlik nie. Die meganisering, industrialisering, en instrumentalisering as prosesse, veral as verabsoluteerde prosesse waardeur ons mensbeeld hersien word, voorsien 'n kosbare teelaarde vir ander aktiwiteite om in dieselfde rigting te beweeg. De Mul (2002) het dit duidelik aangetoon in sy "informatisering van ons wêreldbeeld". In hierdie opsig is dit betekenisvol om te let op die waarskuwing vervat in Salomon (1999) se boek, naamlik om te lewe ondanks of ten spyte van die wetenskappe met die besef dat die wetenskap nie van ons gode maak nie; ook sy latere waarskuwing dat ons ons danksy tegnowetenskap in 'n hoërisikosamelewing bevind (vgl. Salomon, 2006).

Desondanks is daar ander denkers wat ook vanuit 'n wetenskaplike aanslag, maar in 'n minder kritiese en veel meer verwelkomende en omarmende gees, dieselfde gedagtes doelbewus in die naam van die tegnowetenskappe bevorder. Die "kinders van die gees" of "geesteskinders" van Moravec (1988) (verwysende na rekenaars), "die eeu van geestelike masjiene" van Kurzweil (1999) en "digitale syn" van Negroponte (1995) is by uitstek gerig op die gedagte van die verdere ontwikkeling van mense (humane) in die rigting van die posthumane. Die posthumane verteenwoordig hiervolgens nie bloot 'n alternatiewe mensbeeld waarmee mense hulle kan vereenselwig nie, maar die totstandkoming van nuwe, meganies-masjienmatige wesens wat mense verreweg oorskry. Janicaud (2005) se definisie van die kuborg is belangrik. In die een geval sou ons hoogstens kon praat van 'n ander styl van menswees, terwyl ons in die ander geval met 'n hibriede verskynsel te doen het wat deels mens, deels masjien is en wat veral as sodanig die mens ver oorskry (vgl. Andrieu, 2008). Die term posthumaan dui alreeds hierop, terwyl transhumanisme nóg meer sê. Veral in die geval van die transhumanisme word die ontwikkelings ook gesien as ' $n$ voortsetting van die normale evolusieproses, 'n aansienlike verbetering op menswees in terme van sterflikheid, feilbaarheid, veroudering, en veral ook diensbaarheid. In die filmwese word diensbaarheid veral sterk uitgebeeld hierdie posthumane wesens is in diens van gewone mense. In die een geval bied dit 'n ander soort mens, in die ander geval 'n wese met mensoorskrydende funksies wat steeds diensbaar is aan mense. Hoe lank dit gaan duur voordat die volle selfstandigheid wat Moravec (1988) profeteer voluit verwesenlik gaan word, is egter onseker. 
Veral die elektroniese media vervul 'n belangrike rol in die proses. Die filmwese as 'n sterk informatiseringskrag bly nie agterweë nie. Daar is selfs ' $n$ organisasie, World Transhumanist Association, wat hierin betekenisvol meewerk. Die definisie van die transhumanis in hulle manifes lui soos volg:

Transhumanisme is die filosofie wat die gebruik van tegnologie verdedig om ons tekortkomings te bowe te kom en die transformasie van die menslike bestaan te verwesenlik. Die vinnige groei van tegniese ontwikkelings open die vooruitsig op revolusionêre ontwikkelings soos bomenslike kunsmatige intelligensie en molekulêre nanotegnologie. Tot hierdie vooruitsigte behoort ook: die biochemiese verryking en herontwerp van ons lussentra sodat ons 'n ryker verskeidenheid van emosies, lewenslange geluk en daaglikse piekervarings kan ervaar; die beëindiging van veroudering; die afskaffing van siektes; en moontlik die stelselmatige vervanging van die menslike liggaam deur sintetiese onderdele en rekenaars. (Aangehaal deur De Mul, 2002:277; vertaling - CSdeB.)

Moravec (1988) sluit hierby aan. Hy is eksplisiet en stel dat wat op ons wag, die heel beste beskryf word met woorde soos "postbiologies" of selfs "bonatuurlik" (Moravec, 1988:1). Om hier van 'n eskatologiese en selfs ' $n$ apokaliptiese retoriek te praat is sekerlik nie oordrewe nie. Moravec (1988:1) gaan nog verder:

Our machines ... will mature into entities as complex as ourselves, and eventually into something transcending everything we know. ... We will benefit for a time from their labors, but ... they will seek their own fortunes while we ... silently fade away.

Nog meer indrukwekkend:

We are very near the time when virtually no essential human function, physical or mental, will lack an artificial counterpart. The embodiment of this convergence of cultural developments will be the intelligent robot, a machine that can think and act as a human, however inhuman it may be in physical or mental detail. Such machines could carry on our cultural evolution, including their own construction and increasingly rapid selfimprovement, without us, and without the genes that built us. (Moravec, 1988:2.)

In aansluiting hierby gaan hy nog verder:

Sooner or later our machines will become knowledgeable enough to handle their own maintenance, reproduction, and self-improvement without help. When this happens, the new 
genetic takeover will be complete. Our culture will then be able to evolve independently of human biology and its limitations, passing instead directly from generation to generation of ever more capable intelligent machinery. (Moravec, 1988:4.)

Dit bly steeds 'n vraag in watter sin die oordra, aflaai of oplaai van menslike bewussyn in rekenaars as "the new genetic takeover" verstaan kan word. Tot watter mate kan genetika, wat deur en deur op lewende organismes van toepassing is, wel op 'n doenbare wyse op masjiene van toepassing gemaak word?

'n Verdere vraag is of ons dan werklik nog sal kan praat van "ons kultuur" aangesien daar nie meer na "ons" verwys word nie. Die evolusieproses, wat met die Darwinse proses vergelyk word betreffende reproduksie, oorerflikheid, mutasie en verskille in reproduktiewe opvolging, sou bevraagteken kon word, omdat al hierdie onderdele van die proses wesenlik met lewe verband hou en die evolusie hier ter sprake postbiologies, dus na-lewensmatig is. Sou hierdie masjinale denke in der waarheid vergelykbaar wees met menslike denke? Heidegger en baie ander kom na vore: in sover die masjiene wel dink sou ons kon vra of die denke nie bloot die berekenende denke van Heidegger is nie. Sou die masjiene werklik ook versoenbaar wees met die kontemplatiewe, mediterende, refleksiewe denke van Heidegger, die retoriese denke van Lacan, die estetiese denke van Wersig, die newelagtige denke van Atlan, die spekulatiewe denke van Jonas en die esprit de finesse van Pascal? Meer nog, sou dit vir masjiene moontlik wees om die berekenende en die kontemplatiewe denke van die mens as een denke te verwesenlik? Volgens Lyotard (1991) lyk dit nie so nie. Lyotard (1991: 14-15) maak 'n duidelike punt hieroor wanneer hy onderskei tussen "reflektiewe denke" en "afgebakende denke":

Thought without a body is the prerequisite for thinking of the death of all bodies, solar or terrestrial, and of the death of thoughts that are inseparable from those bodies. But 'without a body' in this exact sense: without the complex living terrestrial organism known as the human body. ... Our disappointment in these organs of 'bodiless thought' comes from the fact that they operate on binary logic, one imposed on us by Russell's and Whitehead's mathematical logic, Turing's machine, McCulloch's and Pitt's neuronal model, the cybernetics of Wiener and Von Neumann, Boolian algebra and Shannon's information science. But ... human thought does not think in binary mode. It does not work with units of information (bits), but with intuitive, hypothetical configurations. It accepts imprecise, ambiguous data that don't seem to be selected according to preestablished 
codes or readability. It doesn't neglect side effects or marginal aspects of a situation. It isn't just focused, but lateral too.

Dalk moet op 'n deurslaggewende wyse onderskei word tussen die logiese en die noëtiese in menslike denke.

\section{Die herdink van die menslike subjek, fase 2: 'n komplekse uitdaging}

Daar bestaan skynbaar minstens twee wyses van artikulering van die posthumane. In die een geval is dit ' $n$ mens maar wel ' $n$ ander soort (Hayles, 1999), en aan die ander kant is dit werklik 'n andersoortige wese wat ter sprake is (Moravec, 1988; Die Transhumanistiese Vereniging; De Mul, 2002; Baron, 2008 se muterende vlees as die posthumane fabrikaat; Andrieu, 2008 se hibriede bestaansvorm; asook films soos Blade runner, l-robot en $A /$ ). In latere publikasies het Hayles $(2002$; 2005) die moontlikheid van 'n diversiteit van posthumane beelde geopper.

Indien hierdie nuwe verwikkelings werklik neerkom op die uitsluiting van menslike feilbaarheid, gebrekkigheid en sekerlik ook die kwaad en verder ook dui op onsterflikheid en die uitskakeling van veroudering, verval die nodigheid van etiek en oorwegings van moraliteit klaarblyklik. Etiek moet tog oorbodig wees wanneer sterflikheid en feilbaarheid uitgesluit is.

Sou dit kon beteken dat hier 'n opening geskep word vir monsters, vir die inhumane, waarteen Janicaud (2005) asook Critchley (2005) waarsku? Dit is 'n term wat alreeds deur Heidegger in sy brief oor die humanisme genoem is en waarna Derrida (1982) in sy opstel Ends of man verwys het. Hayles waarsku ook teen die tegnoekstase wat 'n mens maklik meevoer na bestemmings wat geheel en al onbekend is en riskant bly. Of moet/kan ons demokraties aanvaar dat hierdie idilliese nuwe "mens" onbestrede verkies gaan word om ons, die feilbare, sterflike en ouerwordende wesens, te vervang?

Verskillende vrae kom na vore. Daar word aangeneem dat die bewussyn wat in die rekenaar afgelaai of oorgedra word, nie feilbaar of sterflik is nie. Hiermee word die probleem van feilbaarheid, sterflikheid en dus ook van die kwaad nogeens, soos meermale vantevore, na die liggaam verwys waarin hierdie hoogs problematiese dinge gesetel sou wees. Ná Plato, Paulus en Descartes lyk dit nie na 'n groot verrassing nie. Dit is egter nie duidelik op watter gronde en in watter terme die veronderstelde bewussynsuiwerheid van die be- 
wussyn wat oorgedra, afgelaai of opgelaai word, verkondig word nie. Kan dit 'n ideologiese hunkering wees van mense se soeke na 'n beter lewe? Fasette van kwaad, begeerte, wil, onkunde, onderskeidingsvermoë, vryheid, geluksbelewenisse, ensovoorts - alles deel van menswees - kan tog nie almal slegs liggaamlike kenmerke wees wat maklik uitfaseerbaar is wanneer afskeid geneem word van die liggaam nie. Alle herdinkoefeninge moet hiermee rekening hou.

Kan dit terselfdertyd so maklik wees om liggaam en gees/bewussyn te skei? Wanneer Merleau-Ponty beweer dat my liggaam nie net voor my is nie, dat ek nie net 'n liggaam het nie, maar dat ek my liggaam is, vertel dit eerder ' $n$ verhaal van onskeibaarheid. Het hy heeltemal gedwaal en baie ander saam met hom? Inderwaarheid was 'n hele geskiedenis en tradisie op 'n dwaalspoor. Hayles skryf dat die liggaam die resultaat of neerslag is van duisende jare se evolusiegeskiedenis en dat dit naïef sou wees om te dink dat hierdie geskiedenis nie menslike handeling en denke op elke vlak affekteer en bepaal nie. Sogenaamde intelligente masjiene deel nie hierdie geskiedenis nie. Hulle bly op uitsonderlike wyse verskillend van mense in hulle beliggaming (Hayles, 1999:284; vgl. ook Lyotard, 1991; Lecourt, 2003). Vir Lyotard is die probleem hoe om denke sonder die liggaam moontlik te maak, 'n denke wat sou kon voortbestaan na die dood van die menslike liggaam. Hoe sou die nuwe wese boonop ander fasette van menswees soos gevoelsmatigheid, vriendelikheid, taal in die materiële sin en lewe kan demonstreer en vertoon? Posthumane films sukkel heelwat hiermee. Lecourt (2003:121-122) stel dit soos volg:

Die groot filosofiese fout van die verlede was om die liggaam en die gees of bewussyn as twee afsonderlike entiteite te verstaan. Dit is nou nodig om te verstaan dat die hele liggaam, brein ingesluit, deelneem aan die interaksie tussen die mens en die omgewing. ... Die liggaam voorsien aan die brein denkinhoude wat 'n integrerende deel van die normale funksionering daarvan vorm. (Vertaling - CSdeB.)

Dit is baie duidelik dat die mens gekonfronteer is met soveel ontwikkelings en verwikkelings dat dit nie geïgnoreer kan word nie. Daaroor moet diepgaande en ernstig gereflekteer of besin word. Eintlik hang ons lewe en toekoms daarvan af. Hedendaagse werklikhede moet ernstig geneem word. Dit is onvermydelik en bied moontlikhede; het filosofiese relevansie en moet bedink word. Sowel die intrahumane ontwikkelings as die dekonstruktiewe en meganistiese mensbeelde en die posthumane uitdagings stel vrae aan filosowe. 
- Kan mense die genereerders van hulle eie self-oorskrydende evolusie wees? Dit is insiggewend dat die profesieë oor hierdie uitermatige ontwikkelings van die mens verby sigself in die rigting van die kuborg en die posthumane, deurgaans dié van mense is - wensdenkery - sonder om seker te wees dat slegs onfeilbaarheid en onsterflikheid en uitermate flinke denkvernuf al is wat geërf gaan word. Hoe seker is die profeteerders (die tegnoprofete volgens Lecourt, 2009), steeds self uitgelewer aan menslike gebrekkigheid, dat die profesieë suiwer is en nie monsters gaan oproep nie?

- Pas evolusie en die "postbiologiese" bymekaar enindien wel, hoedanig? Is die wesenlike van evolusie nie juis lewe nie? Waarmee het ons te make en wat is werklik bereik wanneer die sogenaamde evolusieproses verby die biologiese beweeg het en die masjinale bereik? Word die kern van ons menswees nie hiermee opgeoffer nie?

- Wat is die waarborg van bewussynsuiwerheid - die bewussyn wat afgelaai of oorgedra moet word - en waarop word hierdie suiwerheid gebaseer? Indien daar ook nog van die onbewuste gepraat word, hoe werk die argumente en motiverings dan, of hoef Freud, Lacan en andere se insigte (die hele psigoanalitiese tradisie wat steeds betekenisvol floreer) nie in hierdie prosesse in ag geneem te word nie?

- Watter soort verband bestaan tussen die liggaam en bewussyn of gees? Kan sodanige verband bloot opgeskort word, of is die verweefdheid van so ' $n$ aard dat dit wedersyds wesensbepalend is? Is ons gebrekkigheid slegs die vloek van liggaamlikheid, of is geestelikheid en bewussyn ewe gebrekkig? Is dit nie moontlik dat dit juis die onbewuste is wat 'n mens in die stof kan laat byt nie? Of meer nog, is dit nie juis die gees, die bewussyn, wat die liggaam so gebrekkig maak nie? Is dit nie waar dat mense doen (liggaamlike handelinge) soos ons dink (bewussynshandelinge) nie? Word die liggaam losgemaak van die gees, en verloor ons liggaamlikheid? Indien die gees losgemaak word van die liggaam, verloor ons geestelikheid?

Word die bewussyn ná die skeiding, gedurende die aflaaiproses, nie bloot 'n abstraksie, 'n matematiese formule, wat rekenaargepas mag wees, maar niks meer mens is nie? Die materiële, soos Hayles (2005) dit begin ontwikkel het en Malabou (2007) daaroor teoretiseer, bring 'n nuwe dimensie van liggaamlikheid 
na vore. Lecourt (2003) het reeds bevestig dat daar 'n onreduseerbare verband tussen liggaam en rede bestaan.

- Die verhouding tussen taal en rekenaar vra aandag. Daar is reeds gewys op die waarskynlike verarming van taal in rekenaarverband. Minc (1987:139-140) skryf:

The language used to converse with the machine will hence be much more widely disseminated. But as we all know, however refined it becomes and whatever efforts are made to make it like ordinary language, it will remain of a special nature. Since it will spread throughout society and virtually take its place beside our ordinary, richly semantic language, the problem is who will continue to develop, maintain or hold on to the latter? Will it not become poorer?

Kan rekenaargelaaide bewussyn werklik die materiële dimensie van taal verwesenlik? Indien taal, volgens Lecercle (2004), die humaniteit van ons menswees skep, as dit die subjek skep, die bewussyn manifesteer en gees-liggaamverbindings lê, hoe verwring gaan "die nuwe mens of wese" nie wees nie? In hierdie verband is die werk van Steiner (2001) van besondere belang.

- Die inligting/kennisdinamiek bring indringende vrae na vore. Epistemiese werklikhede kan nie geprogrammeer word nie. Kennis is te kompleks en die plek en rol van chaos en die stochastiese maak dit onmoontlik vir die kuborg, die posthumane en die transhumanis om te hanteer. Die generering van idees, die vertoef in die domein van idees (die noösfeer), soos deur Morin (1991) in terme van die noölogiese en die noösferiese beskryf, lyk na 'n ontoeganklike domein vir enige posthumane opset, want dit impliseer aktiwiteite wat in 'n transmasjinale werklikheid verloop. Die lag en ween van Plessner (1965) lyk na buitemasjinale ervarings, veral wanneer hy opmerk: "Ek lag, nie my liggaam nie." En wat van die verskynsel "pyn" wat Buytendijk (1961) beskryf as veel meer as blote fisiese of liggaamlike ervarings? Is hierdie verskynsels slegs liggaamlike funksies, of word hulle deur die bionoëtiese materialiteit geïnspireer? Wat van medelye? Sou die bewussyn in die rekenaar nog medelye kan ervaar en met wie en hoe? Die belangrike vraag is dus of ons, in die lig van bogenoemde vrae, nog so maklik van die klassieke mensopvatting kan wegbeweeg. Wat word gemaak met al die aspekte daarvan, soos Janicaud (2005) aandui? Is Ricoeur (1974), Žižek (2000), en baie ander groot denkers oningelig, naïef of weet hulle nie van beter nie; of is Janicaud reg met sy opmerking dat ons nie met iets nuuts te doen het nie en 
dat die soeke na die nuwe meer oor aspirasies en vrese gaan as oor iets anders:

The myth of the cyborg tells us more about our aspirations (and our fears) than about the actual form that new increases in human capacities will take when applied to man himself. Whatever this progress may be (and there certainly will be some), there is no guarantee that it must allow man to transcend his condition. The aspirations that it fetishizes in technology (immortality, invulnerability, sovereign intelligence) are as old as humanity itself. (Janicaud, 2005:33.)

\section{Die herdink van die menslike subjek, fase 3: betekenisvolle inligting van wesenlike belang}

Betekenisvolle inligting is verwesenlikbaar deur die hoogste vorm van geletterdheid, die mees omvattende konsep van verstaan en begrip, want dit bring sin in die samelewing, vestig hoop op die toekoms en gee blyke van 'n geleefde en beleefde kultuur. (Vgl. Bourdieu, 1996; 2001 se opmerkings oor verstaan en Salanskis, 2003 oor hermeneutiek en kognisie.) Vir betekenisvolle inligting vergelyk ook Steiner (1978) se laaste hoofstuk waarin hy beklemtoon dat betekenisvolle inligting ' $n$ kernpunt in toekomsgerigtheid vorm. Dit is belangrik om die gedagtes van Dupuy (1980) te oorweeg. Hy bring die probleem van paradoks na vore: hoe meer inligting, hoe minder betekenis. Let op die voorbeelde van ekonomie en politiek in hierdie verband: hoe meer weelde en rykdom, hoe groter die armoede en swakker die dienste; hoe meer demokrasie, hoe minder harmonie tussen mense. Hiermee saam kan 'n mens ook Illich (1973) lees in verband met bestuur en navorsing: die genesing van swak bestuur is meer bestuur en hoe meer bestuur, hoe groter word die krisisse, of hoe meer probleme wetenskap en tegniek skep, hoe meer navorsing, wetenskap en tegniek is nodig om ons uit die verknorsing te help. Hoe meer krisisse ervaar word, hoe meer vaardighede moet ontwikkel word, maar hoe meer die vaardighede word, hoe meer word die krisisse. Om sonder meer inligting op te gaar en kennisvoorrade op te bou, help ook nie veel nie.

Die eintlike probleem lê by die diagnose van die probleem. Stiegler (2003) beklemtoon dat elke probleem nie net tegnies nie, maar ook sosiaal, ekonomies, psigies en selfs filosofies van aard is. Elke probleem is 'n saak van menslike betekenisgewing of die gebrek daaraan. Elke probleem is dus ook 'n antropologiese probleem. Daarom word betekenisvolle inligting en nie bloot inligting nie, as wesensbelangrik beskou. 
Om by betekenisvolle inligting uit te kom waardeur hierdie paradokse uitgeskakel kan word, is dus die groot uitdaging. Blote interpretasie as die begin van die verstaansproses, vra heelwat meer. Dit is 'n beginpunt, maar nie voldoende nie. Eendimensionele, enkelvoudige denke is ontoereikend. By die interpretasie moet sake soos kommunikasie, distribusie, inferensie, disseminasie, transduksie, en ander oorweeg word. (Vgl. die Hermesreeks van Serres, 1968; 1972; 1974; 1977; 1980 waarin hy hierdie gedagtes ontwikkel het.) Elkeen van hierdie terme herberg ' $n$ eie denkdinamiek wat enige enkelvoudige interpretasieproses aan die raai hou en kompliseer.

Hierdie benadering vra veel meer as die aanvaarding van 'n vaste gegewe betekenis. Dit moet deur 'n vaste gegewe self ontsyfer word om by die waarheid en betekenis oor die self uit te kom. Sake is meervoudig en kompleks. Hierdie kategorieë het alreeds betekenisverskuiwings in die filosofie en in teorie ondergaan en nou ook in tegniese ontwikkelings - veral soos dit die mens raak - en dit het ons by die sogenaamde posthumane mensbeeld uitgebring. Hierdie vooruitsig op die posthumane is 'n bron van terreur en van vreugde, skryf Hayles (1999). Die terreurgedagte is voor die hand liggend: "post" dui op oorskryding van die mens soos ons die wese ken en dui ook op wat daarna volg. Dit dui daarop dat hierdie wese, soos ons dit ken, se dae getel is. Dit is sekerlik 'n skokkende ervaring vir diegene wat veilig en vas in kompartemente vasgemessel is of wil wees. Moravec (1988), Dyer (aangehaal deur Hayles, 1999), en andere glo dat hierdie stelling nie alleen waar is in die algemene intellektuele sin van die vervanging van een definisie van die mens met ' $n$ ander nie, maar ook in 'n meer steurende intellektuele sin, naamlik dat mense as die dominante lewensvorm op aarde deur intelligente masjiene vervang gaan word. Sou dit die vervulling wees van Nietzsche en Foucault se profesieë oor die einde van die mens?

Gelukkig put hierdie sienings nie die gedagte van die posthumane uit nie. Lyotard het in 'n artikel daarop gewys dat intelligensie van liggaamlikheid afhanklik is. Die "intelligensie" van ander "intelligente" wesens sou miskien, indien ons eerlik wil wees, anders genoem moet word, veral as Serres (1997:10) dit interpreteer in terme van sy totaliteitsgedagte: dit is beter om te lewe, te praat en te dink met al ons organe. Die mens is in die eerste plek 'n beliggaamde wese en die kompleksiteite van hierdie liggaamlikheid beteken dat menslike gewaarwording op heeltemal ander wyses ontvou as dié van intelligensie wat in kubernetiese masjiene beliggaam is. Moravec se droom om menslike bewussyn af te laai in 'n rekenaar word nie deur die humaniora gedeel nie. Dit wil egter wel voorkom asof sy 
ontsaglike blindekol ten opsigte van die betekenis van liggaamlikheid in die konteks van tegniek deur baie geesteswetenskappe gedeel word. Deel al die volgelinge van Plato, Paulus en Descartes nie hierdie blindekol nie? Die punt wat hier gemaak word, is dat masjiene op 'n disparaat onderskeidende manier van mense verskil in hulle wyses van liggaamlikheid. Om die waarheid te sê, die outeur (CSdB) betwyfel of ons van 'n masjien se liggaamlikheid, of liewer van die masjien se lyf sou kon praat. Liggaamlikheidstrukture en moontlikhede is die vrug van 'n evolusiegeskiedenis wat intelligente masjiene net nie met mense kan deel nie (vgl. Hayles, 1999). Dat masjiene sosiale, tegniese, politieke, kulturele en intellektuele veranderings teweegbring, is waar en selfs opwindend in die moontlikhede daarvan, maar ons is sekerlik nog ver van die gelykstelling of oorskryding van die mens deur die masjien soos Kurzweil (1999) graag betoog. Myns insiens pleeg hy 'n premature doop vir ons eeu wanneer hy dit "die eeu van die geestelike masjien" noem, veral omdat hy dit in die toekomende tyd doen. Vir die outeur het gees nog altyd meer met warm lywe as met koue masjiene te doen gehad.

Die gedagte van die posthumane bied 'n opwindende vooruitsig om 'n mens uit die ou gevangenskappe waarin ons vasgevang sit te kry en nuwe denkweë te open oor die betekenis van menswees. Hierdie plesier word deur tegniese ontwikkelings aan ons gebied. Daar het 'n verskuiwing plaasgevind van die opposisionele teenwoordigheid/ afwesigheid na patroon/stochastisiteit, of die kansmatige (randomness soos Hayles (1999) dit noem). Ander aannames geld hier. Waar 'n patroon vaste moontlikhede bied, is stochastisiteit nie bloot die afwesigheid van patrone nie, maar die kreatiewe grond waaruit patrone kan ontwikkel en vorm aanneem. In hierdie en soortgelyke modelle is stochastisiteit en nie vastigheid en patrone nie, toegerus met volheid en weelde. Stochastisiteit bestaan buite die raamwerke van die kompartement. Dit dui op die groter en onkenbaarder kompleksiteit wat min of meer alles wat is, omvat en soms ook probeer artikuleer. Dit is merkwaardig dat die gedagte van die stochastiese uit natuurwetenskaplike insigte na vore gekom het (Prigogine \& Stengers, 1986). Betekenisvolle inligting moet uit so 'n meervoudige en veelvormige werklikheid van menswees gekonfigureer word - 'n singuliere meervoudigheid soos Nancy (1996) voorstel, mag die sinvolle uitweg wees. 


\section{Slotopmerkings}

Voor Hayles en teen ander agtergronde en uit ander intellektuele milieus of kennisekologieë is verskeie soortgelyke vergelykings al aangedui om die werklikheid te beskryf: lineariteit/tabulariteit (Serres, 1968); noodsaaklikheid/toeval (Monod, 1979); kristal/rook (Atlan, 1989); reël/paradoks (Lyotard, 1991); normaal/patologies (Canguilhem, 1978); grammatika/retoriek (Lacan, 1977); calculus/aesthesis (Wersig, 1990) en berekenbare/onvoorspelbare (Ekeland, 1988). Wat as werklikheid beskryf word en waaruit objekte geabstraheer word, kan nie slegs met behulp van die eerste term van die begrippepaar verstaan word nie, maar wel in terme van albei. Daarom is dit duidelik dat 'n besondere denkmodus benodig word (kyk De Beer, 2010a in hierdie verband). Hierdie denkers se teoretiese onvergenoegdheid met die patroonmatige het gelei tot 'n hersiening van die subjekopvatting, die kennisopvatting en ook die opvatting van betekenisvolle inligting wat veral hier ter sake is.

Hierdie teoretiese gedagtes word deur inligting- en kommunikasietegniek verder gevoer en verfyn, soos Hayles in haar navorsing daaroor rapporteer. Dit is ontwikkelings wat ' $n$ mens byvoorbeeld wegneem van die gewaarborgde vastighede van betekenis wat vooraf in al die volheid daarvan gegee word en slegs vra vir intelligente ontginning. In teenstelling hiermee word betekenis, volgens haar, nie vooraf gegee nie. Betekenis is dus nooit gewaarborg nie. Dit word moontlik gemaak deur die konfigurerende kragte van die aktiewe inventerende denkvernuf wat daarin geoefen is om konneksies te maak, grense te oorskry en peinsend nuwe konstruksies te ontwerp.

'n Mens moet dit in gedagte hou, soos Varela (1991) en andere al tevore beklemtoon het, dat daar geen stabiele koherente self is, wat alreeds dui op 'n antisipering van die posthumane nie. Patrone in die werklikheid word as beperkings ervaar en slegs soos die gewaarwording verby die bewussyn uitbrei, word hierdie beperkings oorskry en word die leegheid, of dit wat chaos, of selfs die oneindige in ons werklikheidsbetragting genoem kan word, betree.

Sou die posthumane dan nog kan dink en hoe word gedink? Kan so 'n mens nog inventeer? Volgens Fukuyama (2003) is daar steeds 'n identiteit, al sou dit anders beskryf moet word. Hayles (1999) vestig die aandag daarop dat die liberale self opgaan in die eie teenwoordigheid, doelgerigtheid en identifisering met oorspronklike waarborge, maar dat die posthumane besef deurtrek is van die gedagte dat die bewuste gees slegs 'n klein onderdeel uitmaak van 'n groter 
dinamies-komplekse sisteem waarbinne dit verskyn. Dit beteken egter nie die einde van die mens nie, maar wel van 'n bepaalde mensbeeld.

But the posthuman does not really mean the end of humanity. It signals instead the end of a certain conception of the human, a conception that may have applied to that fraction of humanity who had the wealth, power, and leisure to conceptualise themselves as autonomous beings exercising their will through individual agency and choice. What is lethal is not the posthuman as such but the grafting of the posthuman onto a liberal humanist view of the self. (Hayles, 1999:286-287.)

\section{Geraadpleegde bronne}

ANDRIEU, B. 2008. Devenir hybride. Nancy: Presses Universitaires de Nancy. ATLAN, H. 1989. Entre le cristal et la fumée. Paris: Seuil.

BADIOU, A. 2001. Ethics: an essay on the understanding of evil. London: Verso.

BAKER, H. 1961. The image of man. London: Harper \& Row.

BAKKER, R. 1973. Het anonieme denken: Foucault en het structuralisme. Baarn: Wereldvenster.

BAKKER, R. 1981. Wijsgerige antropologie van de twintigste eeuw. Assen: Van Gorcum.

BARON, D. 2008. La chair mutante: fabrique d'un posthumain. Paris: Dis Voir.

BAUDRILLARD, J. 1989. Videowelt und fraktales Subjekt. (In Baudrillard, J., Böhringer, H., Flusser, V., Von Foerster, H., Kittler, F. \& Weibel, P., Hrsg. Philosophien der neuen Technologie: Ars Electronica. Berlin: Merve. S. 113-131.)

BERNS, E., IJSSELING, S. \& MOYART, P. 1979. Denken in Parijs: taal en Lacan, Foucault, Althusser, Derrida. Alphen aan den Rijn: Samson.

BOURDIEU, P. 1996. Understanding. Theory, culture and society, 13(2):17-37.

BOURDIEU, P. 2001. Science de la science et réflexivité. Paris: Éditions Raisons d'Agir.

BUYTENDIJK, F.J.J. 1961. Over de pijn. Utrecht: Het Spectrum.

CADAVA, E., CONNOR, P. \& NANCY, J-L., eds. 1991. Who comes after the subject? New York: Routledge.

CANGUILHEM, G. 1978. On the normal and the pathological. Dordrecht: Reidel.

CRITCHLEY, S. 2005. The overcoming of overcoming. (In Janicaud, D. On the human condition. New York: Routledge. p. vii-xxiv.)

DE BEER, C.S. 2010a. Meervoudige denke: versmoor/vermoor instellings denke? Journal for transcisciplinary research in Southern Africa, 6(3):1.

DE BEER, C.S. 2010b. Pragmatogony: the impact of things on humans. (Forthcomming.)

DE MUL, J. 2002. Transhumanisme: de convergentie van evolutie, humanisme en informatietechnologie. (In De Mul, J. Cyberspace Odyssee. Kampen: Klement. p. 273-295.) 
DELEUZE, G. \& GUATTARI, F. 1988. A thousand plateaus: capitalism and schizophrenia. London: Athlone.

DERRIDA, J. 1982. The ends of man. (In Derrida, J. Margins of philosophy. Sussex: Harvester. p. 109-136.)

DUPUY, J-P. 1980. Myths of the informational society. (In Woodward, K., ed. The myths of information technology and post-industrial culture. London: Routledge \& Kegan Paul. p. 3-17.)

DUPUY, J-P. 2000. The mechanization of the mind: on the origins of cognitive science. Princeton: Princeton University Press.

EKELAND, I. 1988. Mathematics and the unexpected. Chicago: University of Chicago Press.

FAUBION, J.D., ed. 1995. Rethinking the subject. Boulder: Westview.

FOUCAULT, M. 1970. Words and things. London: Tavistock.

FOUCAULT, M. 2008. Le gouvernement de soi et des autres. Paris: Gallimard/Seuil.

FOUCAULT, M. 2009. Le courage de la vérité. Paris: Gallimard/Seuil.

FUKUYAMA, F. 2003. Our post-human future: consequences of the biotechnology revolution. New York: Picador.

GUATTARI, F. 1995. Chaosmosis: an ethico-aesthetic paradigm. Bloomington: Indiana University Press.

HABERMAS, J. 2002. Die Zukunft der menslichen Natur: auf dem Weg zu einer liberalen Eugenik? Frankfurt am Main: Suhrkamp.

HAYLES, N.K. 1999. How we became posthuman: virtual bodies in cybernetics, literature and informatics. Chicago: University of Chicago Press.

HAYLES, N.K. 2002. Writing machines. Cambridge: MIT.

HAYLES, N.K. 2005. My mother was a computer: digital subjects and literary texts. Chicago: University of Chicago Press.

HEIDEGGER, M. 1973. Brief over het humanisme. Tielt: Lannoo.

HEIDEGGER, M. 1983. De tijd van het wereldbeeld. Tielt: Lannoo.

ILLICH, I. 1973. Tools for conviviality. London: Calder \& Boyars.

JANICAUD, D. 2005. On the human condition. New York: Routledge.

KURZWEIL, R. 1999. The age of the spiritual machines: when computers exceed human intelligence. New York: Penguin Putnam.

KWANT, R. 1973. Mensbeelden: filosofie in een pluriforme samenleving. Alphen aan den Rhijn: Samson.

LACAN, J. 1977. The subversion of the subject and the dialectic of desire in the Freudian unconscious. (In Lacan, J. Ecrits: a selection. London: Tavistock. p. 292-325.)

LACAN, J. 1986. Le séminaire. Livre 7: L'éthique de la psychanalyse. Paris: Seuil.

LACOUE-LABARTHE, Ph. \& NANCY, J-L. 1981. Les fins de l'homme: à partir du travail de Jacques Derrida. Paris: Galilée.

LECERCLE, J-J. 2004. Une philosophie Marxiste du langage. Paris: PUF.

LECOURT, D. 2003. Humain, posthumain. Paris: PUF.

LECOURT, D. 2009. L'âge de la peur. Paris: Bayard.

LYOTARD, J-F. 1991. The inhuman: reflections on time. Stanford: Stanford University Press.

MALABOU, C. 2007. Les nouveaux blessés: de Freud à la neurologie, penser les traumatismes contemporains. Paris: Bayard.

MINC, A. 1987. The informatisation of society. (In Cawkell, A.E., ed. Evolution of an information society. London: Aslib. p. 134-140.) 
MONOD, J. 1979. Chance and necessity. Glasgow: Collins. (Fount Paperbacks.)

MORAVEC, H. 1988. Mind children: the future of robot and human intelligence. Cambridge: Harvard University Press.

MORIN, E. 1991. La méthode: Vol. 4: Les idées: leur habitat, leur vie, leurs moeurs, leur organisation. Paris: Seuil.

NANCY, J-L. 1996. Being singular plural. Stanford: Stanford University Press.

NEGROPONTE, N. 1995. Being digital. New York: Knopf.

PLESSNER, H. 1965. Lachen en weenen. Utrecht: Spectrum.

PRIGOGINE, I. \& STENGERS, I. 1986. Order out of chaos. New York: Beacon.

RICOEUR, P. 1974. The question of the subject: the challenge of semiology. (In Ricoeur, P. The conflict of interpretations. Evanston: Northwestern University Press. p. 236-266.)

SALANSKIS, J-M. 2003. Herméneutique et cognition. Lille: Presses Universitaires du Septentrion.

SALOMON, J-J. 1999. Survivre à la science: une certaine idée du futur. Paris: Albin Michel.

SALOMON, J-J. 2006. Une civilisation à hauts risques. Paris: Charles Léopold Mayer.

SERRES, M. 1968. Hermes. Vol. 1: La communication. Paris: Minuit.

SERRES, M. 1972. Hermes. Vol. 2: L'interférence. Paris: Minuit.

SERRES, M. 1974. Hermes. Vol. 3: La traduction. Paris: Minuit.

SERRES, M. 1977. Hermes. Vol. 4: La distribution. Paris: Minuit.

SERRES, M. 1980. Hermes. Vol. 5: Le passage du Nord-Ouest. Paris: Minuit.

SERRES, M. 1987. Statues. Paris: Bourin.

SERRES, M. 1997. The troubadour of knowledge. Ann Arbor: University of Michigan Press.

SERRES, M. 2001. Hominescence. Paris: Le Pommier.

SERRES, M. 2006. Récits d'Humanisme. Paris: Le Pommier.

SINGER, W. 2003. Ein neues Menschenbild? Frankfurt am Main: Suhrkamp.

SOPER, K. 1986. Humanism and anti-humanism: problems of modern European thought. London: Hutchinson.

STEINER, G. 1978. In Bluebird's castle: some notes towards the redefinition of culture. London: Faber \& Faber.

STEINER, G. 2001. Grammars of creation. London: Faber \& Faber.

STIEGLER, B. 2001. La technique et le temps. Vol. 3: Le temps du cinéma et la question du mal-être. Paris: Galilée.

STIEGLER, B. 2003. Aimer, s'aimer, nous aimer. Paris: Galilée.

VARELA, F.J. 1991. The embodied mind: cognitive sciences and human experience. Cambridge: MIT.

WERSIG, G. 1990. The changing role of knowledge in an information society. (In Foskett, D.J., ed. The information environment: a world view. Amsterdam: Elsevier. p. 185-198.)

WERSIG, G. 1995. Fokus Mensch. Frankfurt am Main: Peter Lang.

ŽlŽEK, S. 2000. The ticklish subject. London: Verso.

ZUPANČIČ, A. 2000. Ethics of the real: Kant, Lacan. London: Verso. 


\section{Kernbegrippe:}

bewussyn

liggaamlikheid

mensbeeld

posthumane

subjek

Key concepts:

bodiliness

consciousness

image of the human being

posthuman

subject 
